\title{
Ketepatan pemilihan pendekatan, metode, dan media terhadap karakteristik materi IPA
}

\author{
Rusyda Mutanaffisah $^{1}{ }^{*}$, Resmi Ningrum $^{1,2}$, Ari Widodo $^{1}$ \\ ${ }^{1}$ Universitas Pendidikan Indonesia. Jl. Dr. Setiabudi No.229, Bandung, Jawa Barat 40154 Indonesia \\ ${ }^{2}$ Sekolah Menengah Pertama Negeri 51 Bandung. Jl. Raya Derwati, Kota Bandung, 40296, Indonesia \\ * Coressponding Author. E-mail: rusydaamutanaffisah@gmail.com
}

Received: 22 June 2020; Revised: 3 March 2021; Accepted: 10 March 2021

\begin{abstract}
Abstrak: Paper ini memaparkan hasil analisis video kegiatan pembelajaran untuk membandingkan ketepatan pemilihan strategi pengajaran (pendekatan, metode, dan media) oleh tiga subjek penelitian yang memiliki jenjang karier berbeda. Ketiga subjek tersebut adalah mahasiswa jurusan pendidikan yang sedang melakukan simulasi di kelasnya, mahasiswa tingkat akhir yang sedang melakukan Program Pengalaman Lapangan (PPL), dan guru berpengalaman. Hasil analisis menunjukkan bahwa guru berpengalaman menggunakan pendekatan, metode, dan media yang tepat dan lebih variatif dibandingkan mahasiswa. Selain itu, guru berpengalaman cenderung lebih menguasai materi pembelajaran dan mampu mengaitkan pembelajaran dengan kehidupan sehari-hari. Hal ini juga teramati pada mahasiswa PPL yang menggunakan fenomena sehari-hari sebagai bahan diskusi. Meski demikian, ketiga subjek memperlihatkan pola distribusi waktu penyajian konsep yang relatif sama, yaitu lebih dari 90\% pada kegiatan inti dan kurang dari 5\% untuk kegiatan pendahuluan dan penutup. Paper ini diharapkan dapat menyajikan gambaran mengenai realita yang terjadi di lapangan sebagai bahan evaluasi dalam pembelajaran IPA, baik untuk mahasiswa, guru, ataupun semua pihak yang terkait di dunia pendidikan.
\end{abstract}

Kata Kunci: pendekatan, media, metode, Ilmu Pengetahuan Alam

\section{The accuracy of the selection of approaches, methods, and media for the characteristics of combined science materials}

\begin{abstract}
This paper presents the results of a video analysis of learning activities to compare the accuracy of the selection of teaching strategies (approaches, methods, and media) by three subjects with different career paths. The three subjects are college students majoring in education conducting simulations in the classroom, final-year college students conducting a Field Experience Program (PPL), and experienced teachers. The results of the analysis show that experienced teachers use the right approach, method, and media that are more varied than both students. Besides, experienced teachers tend to be better at learning material and are able to link learning to everyday life. This was also observed in PPL students who used everyday phenomena as the discussion material. However, the three subjects showed a relatively similar time distribution pattern of the concept presentation, which is more than $90 \%$ in core activities and less than 5\% for preliminary and closing activities. This paper is expected to present a picture of the reality that occurs in the field as an evaluation material in learning science, both for students, teachers, or all parties involved in the world of education.
\end{abstract}

Keywords: approach, media, method, Combined Science

How to Cite: Mutanaffisah, R., Ningrum, R., \& Widodo, A. (2021). Ketepatan pemilihan pendekatan, metode, dan media terhadap karakteristik materi IPA. Jurnal Inovasi Pendidikan IPA, 7(1), 12-21. doi:https://doi.org/10.21831/jipi.v7i1.32622

\section{PENDAHULUAN}

Ilmu Pengetahuan Alam (IPA) merupakan cabang ilmu yang bersifat dinamis dan saling berkaitan dengan cabang ilmu lainnya. Pada kenyataannya, masih banyak siswa yang memiliki pemikiran bahwa IPA merupakan kumpulan fakta yang statis, mutlak, dan harus dihapal. Kesalahan pemikiran tersebut terjadi karena guru belum banyak memberikan pemahaman mengenai hakikat IPA pada kegiatan pembelajaran di kelas (Ali et al., 2013; McComas et al., 2002). Salah satu penyebabnya adalah karena tingkat pemahaman guru yang masih rendah (Adi \& Widodo, 2018; Jumanto \& Widodo, 2018; 


\section{Jurnal Inovasi Pendidikan IPA, 7 (1), 2021 - 13}

Rusyda Mutanaffisah, Resmi Ningrum, Ari Widodo

Rochintaniawati et al., 2009). Pemahaman mengenai hakikat IPA perlu dimiliki siswa untuk membantu mereka memahami materi (Mariana \& Praginda, 2009). Namun, lebih dari itu, pengetahuan dan pemahaman guru mengenai hakikat IPA akan memengaruhi mereka dalam memilih strategi pengajaran yang akan digunakan (McComas et al., 2002). Dari sini kita bisa melihat bahwa pemahaman hakikat IPA berhubungan dengan kemampuan pedagogik guru. Kemampuan pedagogik berhubungan dengan praktik mengajar guru dalam menyajikan pelajaran. Tingkat pemahaman hakikat IPA yang rendah menunjukkan bahwa guru tidak menguasai pedagogik dengan baik sehingga cara penyajian pelajaran bisa menjadi tidak tepat.

Hasil penelitian skala internasional yaitu TIMSS (Mullis et al., 2016) dan PISA (Schleicher, 2019) menunjukkan bahwa hasil belajar siswa di Indonesia masih dibawah rata-rata. Padahal, soal-soal yang ada di dalam TIMSS maupun PISA merupakan soal-soal yang kontekstual. Hal ini kemungkinan besar disebabkan karena ketidaktepatan guru dalam menyajikan pembelajaran. Guru kurang mengaitkan materi yang sedang dibahas dengan konteks kehidupan (Ali et al., 2013; Rochintaniawati et al., 2009), sehingga siswa kesulitan mengaplikasikannya. Selain itu, umumnya pembelajaran IPA dilakukan di dalam kelas sehingga peserta didik kurang berinteraksi dengan media dan sumber belajar lain. Hal tersebut membuat pembelajaran cenderung bersifat tekstual dan hanya menekankan pada penyelesaian materi pelajaran. Guru lebih memilih untuk menggunakan metode ceramah (Rochintaniawati et al., 2009) terutama dalam membelajarkan materi IPA yang mereka anggap sulit (Insani, 2016). Akibatnya, pengalaman peserta didik hanya sebatas mendengar dan mencatat penjelasan guru (Sitanggang \& Yulistiana, 2015). Kebanyakan guru juga belum menguasai berbagai variasi pendekatan sehingga tidak bisa menerapkannya dalam pembelajaran IPA di kelas (Maryanto \& Hariyatmi, 2017).

Seperti diketahui bahwa dalam kegiatan pembelajaran, guru tidak hanya perlu menguasai pengetahuan mengenai konten materi IPA atau Content Knowledge (CK), namun juga harus mampu memperkaya wawasannya mengenai perkembangan pengetahuan pedagogik atau Pedagogical Knowledge (PK) dan pengetahuan konten pedagogi atau Pedagogical Content Knowledge (PCK) (Insani, 2016; Loughran et al., 2012). PCK mungkin tidak secara langsung berhubungan dengan kualitas pengajaran guru, namun, PCK dapat menjadi indikator yang baik dari potensi guru untuk menyampaikan pengajaran yang berkualitas (Widodo, 2017a). Guru dengan PCK yang kuat akan akan menyajikan pelajaran dengan lebih efektif dan mendukung pembelajaran siswa (Widodo, 2017b).

Salah satu faktor yang memengaruhi kemampuan PCK guru adalah pengalaman mengajar (Kastutik \& Hariyatmi, 2017; Putra et al., 2017). Kemampuan PCK guru di setiap sekolah berbeda (Chotimah \& Hariyatmi, 2017), namun umumnya guru berpengalaman menunjukkan kemampuan PCK yang terkategori baik. Hal ini juga terlihat pada kemampuan PCK calon guru yang mengalami peningkatan setelah mendapatkan pengalaman praktik mengajar (Großschedl et al., 2015; Padila et al., 2017). Calon guru sebenarnya sudah bisa menentukan dan memilih strategi pembelajaran untuk mencapai Kompetensi Dasar pembelajaran, namun belum mampu menerapkannya secara maksimal (Sukaesih, Ridlo, \& Saptono, 2017) karena kurangnya pengalaman. Pengalaman mengajar akan membuat seorang guru mampu mengembangkan strategi pembelajaran materi IPA yang tepat sesuai karakteristik siswa dan materinya (Anwar et al., 2016).

Setiap materi dalam pelajaran IPA memiliki karakteristik yang khas. Beberapa materi bisa diajarkan secara tradisional dengan menggunakan metode ceramah dan tanya jawab. Namun, beberapa materi perlu dibahas melalui kegiatan diskusi dan eksperimen. Beberapa konsep perlu diajarkan secara berurutan dan sistematis, namun konsep lainnya dapat berupa pengetahuan yang bisa langsung diperoleh dari pengalaman dan pengamatan sehari-hari (Cakir, 2008). Meskipun tidak ada cara terbaik mengajar setiap materi IPA yang berlaku secara universal, guru IPA perlu mengetahui bagaimana karakteristik setiap materi dan karakteristik siswa mereka agar dapat berhasil mengajarkan materi dengan dengan efektif dan efisien (National Research Council, 1997; Insani, 2016).

Berbagai penelitian untuk melihat gambaran kegiatan pembelajaran IPA di kelas sudah pernah dilakukan terhadap guru berpengalaman (Rochintaniawati et al., 2009; Widodo, 2006, 2017a). Hasil penelitian-penelitian tersebut menunjukkan bahwa tidak semua guru berpengalaman telah mampu memaksimalkan waktu dan strategi pembelajaran secara efektif dan efisien. Di sisi lain, penelitian mengenai perbandingan ketepatan pemilihan strategi pembelajaran mahasiswa jurusan pendidikan, mahasiswa PPL, dan guru berpengalaman belum banyak dilakukan. Padahal, data tersebut bisa memberikan gambaran mengenai persamaan ataupun perbedaan yang ada pada ketiga kelompok tersebut. Selain itu, pandangan bahwa guru berpengalaman akan lebih baik dari mahasiswa yang cenderung 


\section{Jurnal Inovasi Pendidikan IPA, 7 (1), 2021 - 14}

Rusyda Mutanaffisah, Resmi Ningrum, Ari Widodo

kurang pengalaman juga akan dapat dijelaskan dengan melakukan penelitian mengenai perbandingan antara ketiganya. Oleh karena itu, paper ini akan memaparkan hasil analisis berdasarkan data empiris mengenai perbandingan strategi pembelajaran yang dilakukan oleh mahasiswa jurusan pendidikan, mahasiswa PPL, dan guru berpengalaman. Penelitian ini bisa menjadi bahan evaluasi dan refleksi untuk masing-masing kelompok dan menjadi pembelajaran untuk kegiatan pembelajaran IPA selanjutnya.

\section{METODE}

Penelitian menggunakan analisis deskriptif dari data yang didapatkan. Subjek penelitian terdiri dari 3 partisipan yang berasal dari kelompok yang memiliki jenjang karier berbeda, yaitu mahasiswa tingkat 3 jurusan pendidikan yang melakukan simulasi pembelajaran di kelasnya, mahasiswa yang sedang melakukan PPL, dan guru IPA yang berpengalaman. Data penelitian dari ketiga subjek diambil dengan melakukan observasi kegiatan pembelajaran selama satu pertemuan dari masing-masing partisipan. Observasi tidak dilakukan peneliti secara langsung di kelas, namun dengan merekamnya menjadi video. Penggunaan video memungkinkan peneliti untuk dapat menggambarkan proses pembelajaran secara lengkap dan dapat diulang-ulang bila perlu untuk mendapat kejelasan. Kelebihan lain menggunakan video adalah dapat menggabungkan analisis kualitatif dan kuantitatif dengan cara yang tidak mungkin dilakukan dengan jenis data yang lain, dapat memberikan referensi untuk deskripsi guru tentang kualitas pengajaran, dapat memfasilitasi komunikasi hasil penelitian, serta dapat menyediakan sumber gagasan baru untuk cara mengajar. Namun, penggunaan video juga memiliki kekurangan, yaitu siswa dan guru dapat mengubah perilaku alaminya selama perekaman video (Stigler et al., 1999).

Video yang didapatkan dari ketiga subjek kemudian diamati masing-masing sebanyak minimal tiga kali. Pemutaran video pertama kali ditujukan agar peneliti bisa mendapatkan gambaran keseluruhan kegiatan pembelajaran. Namun, peneliti juga mencatat beberapa hal lain yang teramati, misalnya kegiatan yang dilakukan di luar pembelajaran atau pembahasan konsep. Pada pemutaran video yang kedua, peneliti mulai fokus untuk mencatat konsep-konsep yang dibahas oleh guru selama kegiatan pendahuluan, inti, dan penutup. Untuk mendapatkan hasil analisis yang lebih detail, peneliti menggunakan software tertentu sehingga video dapat diatur agar terus berputar berulang-ulang setiap sepuluh detik. Hasil analisis dibuat dalam sebuah diagram alur untuk mendapatkan gambaran kegiatan pembelajaran, konsep-konsep yang dibahas, serta masing-masing waktu pembahasannya. Selanjutnya, peneliti akan mulai menganalisis pendekatan, metode, dan media yang digunakan guru untuk membahas setiap konsep dari pemutaran video yang ketiga.

Ketiga subjek mengajarkan materi yang berbeda dan dengan durasi waktu yang berbeda pula. Mahasiswa membahas "Ekosistem: Rantai dan Jaring-jaring Makanan" untuk kelas 7, mahasiswa PPL membahas "Organ Ekskresi: Kulit" untuk kelas 8, sementara guru berpengalaman membahas "Massa Jenis" untuk kelas 7. Meskipun berbeda materi, namun ketiga subjek sama-sama mengajarkan konsep dalam pelajaran IPA untuk SMP. Oleh karena adanya perbedaan materi ini, penelitian hanya akan difokuskan untuk membahas pemilihan pendekatan, metode, dan media oleh masing-masing subjek penelitian.

\section{HASIL DAN PEMBAHASAN}

Sebelum membahas mengenai strategi pembelajaran yang digunakan, pada paper ini akan dipaparkan gambaran kegiatan pembelajaran dari ketiga subjek penelitian. Perbandingan persentase distribusi waktu untuk pembahasan konsep antara ketiga subjek penelitian dapat dilihat pada Gambar 1 .

Secara sekilas, dapat terlihat bahwa guru berpengalaman memiliki nilai persentase penggunaan waktu untuk kegiatan pembelajaran yang paling sedikit dibandingkan dengan kedua mahasiswa. Hasil analisis video menunjukkan bahwa ketiga subjek menggunakan waktu di luar kegiatan pembelajaran dengan kegiatan seperti pendisiplinan siswa (pengorganisasian siswa sebelum praktikum atau kegiatan berkelompok) dan jeda menunggu waktu tanggapan atau respon siswa ketika berdiskusi. Selain itu, mahasiswa PPL dan guru berpengalaman juga beberapa kali memberikan motivasi kepada siswa dalam belajar. Guru berpengalaman bahkan menghubungkan motivasi tersebut dengan kisah ilmuwan yang sedang dibahas dalam kegiatan pembelajaran, yaitu Archimedes. Dalam pembelajaran terutama pelajaran IPA, kegiatan seperti ini perlu dilakukan karena guru berperan sangat penting dalam membentuk kepercayaan diri, mindset, dan kemampuan siswa untuk fokus dan bersungguh-sungguh dalam belajar (Darling-Hammond et al., 2020). Namun, hanya guru berpengalaman yang menghubungkan pembel- 
Jurnal Inovasi Pendidikan IPA, 7 (1), 2021 - 15

Rusyda Mutanaffisah, Resmi Ningrum, Ari Widodo

ajaran dengan kebermanfaatannya dalam kehidupan sehari-hari, sedangkan yang lainnya tidak melakukan hal ini.

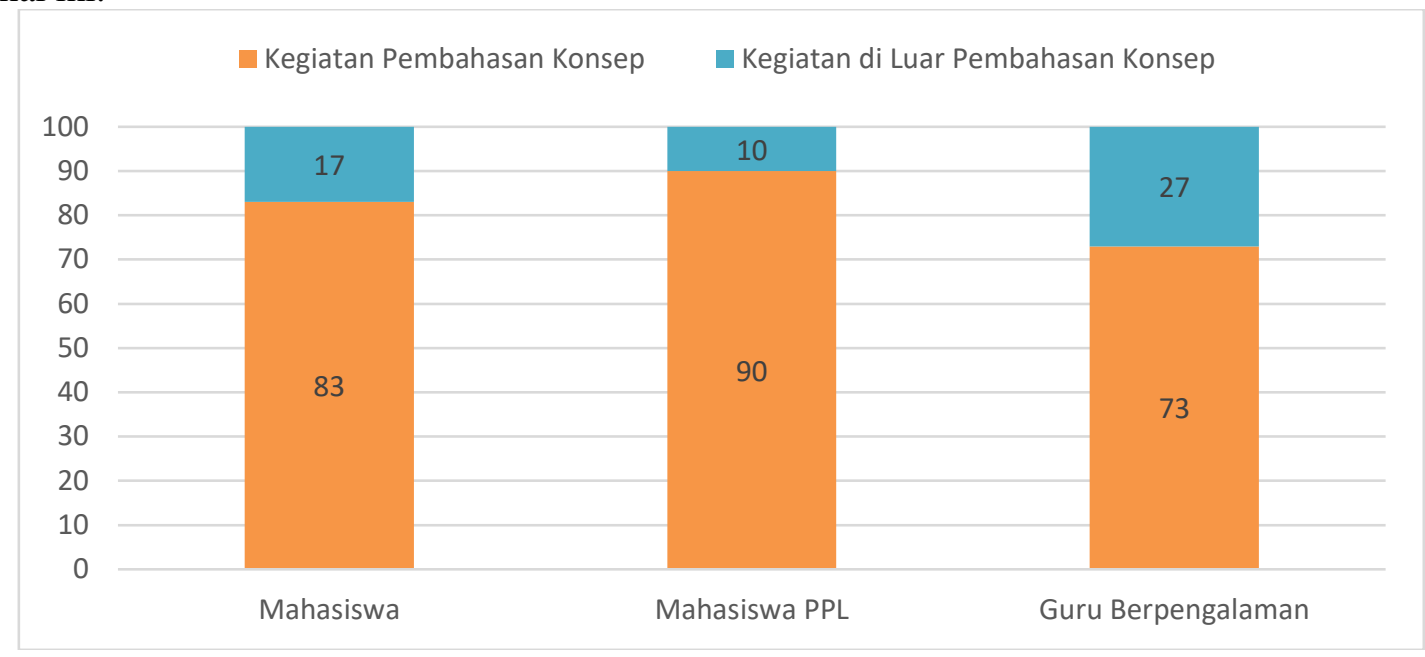

Gambar 1. Persentase Distribusi Penggunaan Waktu Selama Kegiatan Pembelajaran

Secara umum, kegiatan pembelajaran dapat dibagi menjadi 3 tahap, yaitu tahap pendahuluan/ awal, inti, dan penutup (Majid, 2008). Ketiga subjek penelitian memiliki total durasi mengajar yang berbeda, sehingga pada paper ini digunakan nilai persentase untuk melihat perbandingan distribusi penggunaan waktu yang digunakan dalam kegiatan pembelajaran. Perbandingan distribusi waktu pembahasan konsep di setiap tahap kegiatan pembelajaran dapat dilihat pada Gambar 2.

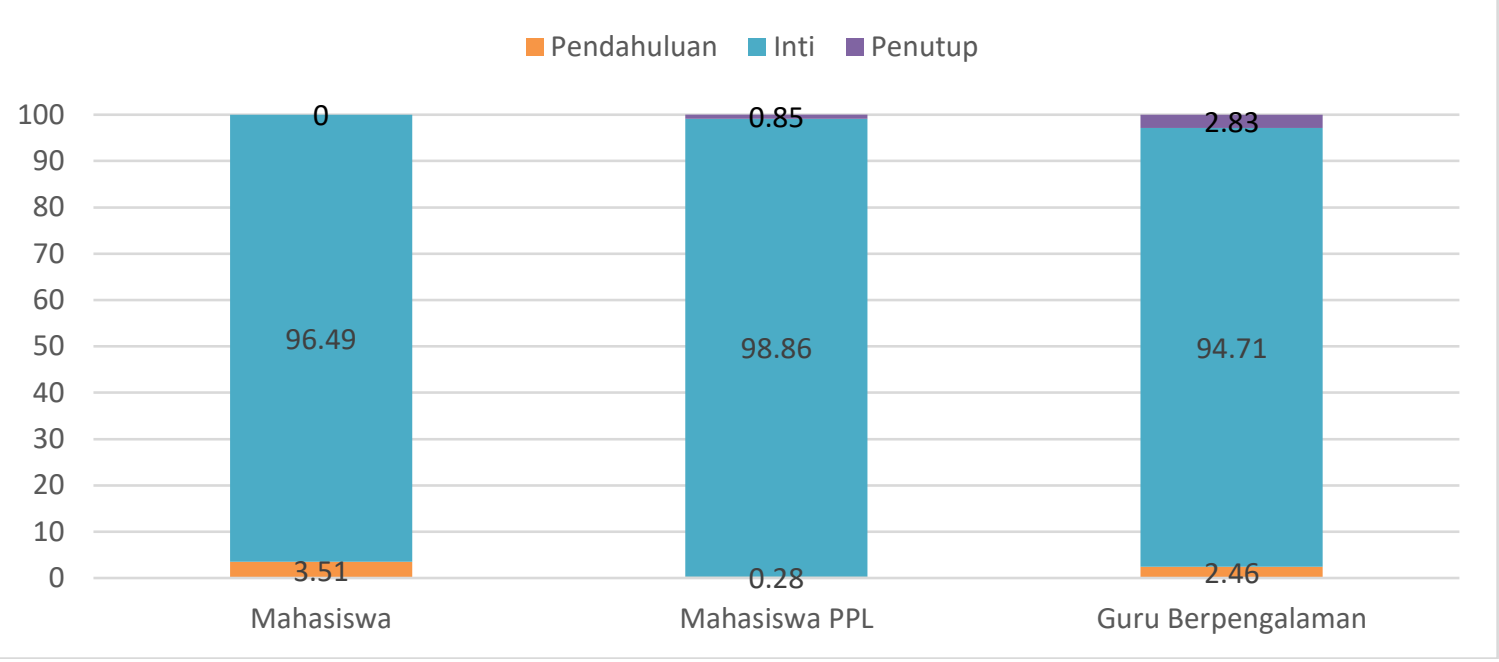

Gambar 2. Persentase Distribusi Waktu Pembahasan Konsep di Setiap Tahap Kegiatan Pembelajaran

Secara keseluruhan, dapat dilihat bahwa distribusi waktu untuk tahap inti oleh ketiga subjek penelitian memiliki persentase yang paling besar, bahkan hingga melebihi $90 \%$. Hal ini menunjukkan bahwa ketiga subjek penelitian sudah memaksimalkan pembahasan konsep pada tahap inti dengan baik. Tahap inti merupakan tahap yang paling penting karena pada tahap inilah terjadinya proses pembelajaran yang sebenarnya. Namun, dari ketiganya, hanya guru berpengalaman yang membahas konsep pada saat kegiatan penutup. Padahal, pada tahap penutup, guru seharusnya mengajak siswa untuk menyimpulkan pembelajaran (Rochintaniawati et al., 2009) dan mengaitkannya dengan konsep yang akan dipelajari pada pertemuan berikutnya. Pembahasan konsep pada bagian penutup sangat sebentar dilakukan oleh mahasiswa PPL dan bahkan tidak dilakukan sama sekali oleh mahasiswa. Hasil yang sama juga terlihat pada penelitian sebelumnya terhadap calon guru biologi (Sukaesih et al., 2017). Hal ini menunjukkan bahwa hanya guru berpengalaman yang mampu memaksimalkan kegiatan penutup dengan baik. Analisis lebih lanjut menunjukkan bahwa ketiga subjek penelitian menggunakan strategi pembelajaran yang berbeda dalam menjelaskan materi yang sifatnya berbeda. Strategi pembelajaran yang diamati 
Jurnal Inovasi Pendidikan IPA, 7 (1), 2021 - 16

Rusyda Mutanaffisah, Resmi Ningrum, Ari Widodo

adalah dalam hal dalam pemilihan pendekatan, metode, dan media. Perbedaan sifat materi dan pemilihan strategi pembelajaran oleh ketiga subjek penelitian dapat dilihat pada Tabel 1.

Tabel 1. Pendekatan, Metode, dan Media yang Digunakan Ketiga Subjek Penelitian

\begin{tabular}{|c|c|c|c|c|c|}
\hline No. & Subjek & Sifat Materi & Pendekatan & Metode & Media \\
\hline 1. & Mahasiswa & Perlu observasi & Konsep & Ceramah & Teks dan gambar \\
\hline 2. & Mahasiswa PPL & Perlu visualisasi & Konsep, konstruktivisme & Ceramah, diskusi & Gambar \\
\hline 3. & $\begin{array}{l}\text { Guru } \\
\text { berpengalaman }\end{array}$ & Eksploratif & Konsep, proses, historis & $\begin{array}{l}\text { Ceramah, diskusi, } \\
\text { praktikum }\end{array}$ & $\begin{array}{l}\text { Teks, gambar, } \\
\text { video, contoh } \\
\text { benda-benda padat }\end{array}$ \\
\hline
\end{tabular}

\section{Pemilihan Pendekatan}

Berdasarkan Tabel 1, dapat dilihat bahwa ketiga subjek penelitian memilih pendekatan konsep sebagai salah satu pendekatan yang digunakan selama kegiatan pembelajaran. Namun, hanya mahasiswa yang memilih pendekatan konsep sebagai satu-satunya pendekatan yang digunakan. Jika dibandingkan dengan mahasiswa, mahasiswa PPL dan guru berpengalaman sudah menggunakan pendekatan konsep dengan tepat. Pemilihan pendekatan dalam pembelajaran sangat penting. Guru yang menerapkan pendekatan yang inovatif bisa mengembangkan keterampilan berpikir dan keterampilan proses siswa (Sukaesih, Ridlo, \& Saptono, 2019).

Pemilihan pendekatan konsep oleh mahasiswa tidak cukup untuk membelajarkan materi mengenai "Ekosistem" yang sifatnya perlu observasi. Pendekatan konsep memang diperlukan untuk mencegah miskonsepsi mengenai zat, energi, siklus nutrisi, dan aliran energi pada materi ekosistem (National Science Teachers Association, 2009), namun konsep ini akan lebih baik dipahami dan dimaknai siswa dengan pendekatan lingkungan (Widodo, Rachmadiarti, \& Hidayati, 2017). Guru bisa mengajak siswa secara berkelompok untuk mengamati lingkungan sekitar, kemudian siswa mengelompokkan komponen biotik dan abiotik lalu membuat rantai makanan dan jaring-jaring makanan.

Mahasiswa PPL menggunakan pendekatan konsep dan konstruktivisme dalam kegiatan pembelajaran. Dari total 12 konsep, hanya ada 2 konsep yang menggunakan pendekatan konsep yaitu kulit dan aktivitas tubuh sebagai konsep awal yang digunakan pada tahap pendahuluan diskusi. Pemilihan pendekatan konstruktivisme dalam pembelajaran materi ini kurang tepat. Pembahasan materi ekskresi ini sebaiknya menggunakan pendekatan saintifik (Zubaidah et al., 2017). Selain itu, mahasiswa PPL juga dapat menerapkan pendekatan proses, yaitu dengan memberikan aktivitas yang menunjukkan proses pembentukan keringat. Misalnya, dengan meminta beberapa siswa untuk berlari di tempat atau melakukan aktivitas (olahraga) tertentu. Setelah itu, mahasiswa PPL bisa menghubungkan konsep pembentukan keringat dengan konsep suhu, detak jantung, pori-pori, dan bau badan.

Guru berpengalaman menggunakan 3 jenis pendekatan berbeda selama kegiatan pembelajaran, yaitu pendekatan konsep, proses, dan historis. Ketiga pendekatan ini digunakan secara tepat oleh guru. Pendekatan konsep digunakan dengan menghubungkan konsep yang sedang dipelajari dengan konsepkonsep yang telah dipelajari sebelumnya. Pendekatan proses digunakan untuk membangun pemahaman konsep utama pembelajaran yang sifatnya eksploratif, yaitu mengenai massa jenis. Para siswa secara berkelompok melakukan kegiatan pengukuran massa jenis dan mendapatkan pemahaman mengenai massa jenis melalui kegiatan tersebut. Hal ini sejalan dengan apa yang disarankan di dalam buku pegangan guru, bahwa untuk mengajarkan konsep ini sebaiknya menggunakan pendekatan proses (Widodo et al., 2017). Selain pendekatan proses, guru berpengalaman juga menggunakan pendekatan konsep dan historis, sehingga lebih bervariatif dan melebihi pendekatan yang disarankan dalam buku pegangan guru. Pendekatan historis digunakan guru untuk memberikan pemahaman awal sebelum siswa memahami konsep massa jenis. Guru menyajikan sebuah cerita di masa lalu mengenai penemuan Archimedes dan bagaimana penemuannya berguna hingga saat ini, terutama dalam mengetahui nilai massa jenis. Strategi pemilihan pendekatan historis pada materi massa jenis ini sudah tepat. Hal ini terlihat dari bagaimana siswa akhirnya mampu mensimulasikan penemuan Archimedes dan menghubungkan pentingnya pemahaman tersebut dalam kehidupan sehari-hari. Pendekatan historis yang digunakan dalam pembelajaran IPA tidak hanya menarik untuk siswa yang menyukai pelajaran IPA, tapi juga untuk siswa yang kurang menyukai IPA karena berbagai alasan, misalnya karena mereka menganggap konsep dalam IPA sulit dipahami, atau karena mereka tidak menyukai rumus dan perhitungan (Mamlok-Naaman et al., 2005). 


\section{Pemilihan Metode}

Ketiga subjek menggunakan metode yang berbeda sesuai sifat materi pelajaran yang dibahas. Namun, sama seperti pada pemilihan pendekatan, guru berpengalaman menggunakan metode yang lebih variatif dibandingkan mahasiswa dan mahasiswa PPL. Ketiganya menggunakan metode ceramah. Namun, hanya mahasiswa yang menggunakan metode ceramah ini sebagai satu-satunya metode yang digunakan selama kegiatan pembelajaran, meskipun penggunaannya kurang tepat untuk karakteristik materi Ekosistem. Mahasiswa PPL dan guru berpengalaman yang sudah tepat menerapkan metode ceramah dan menggabungkannya dengan metode lain, seperti diskusi. Guru berpengalaman bahkan menambahkan pendekatan historis sebelum masuk ke dalam kegiatan inti berupa praktikum. Kurangnya variasi yang digunakan mahasiswa kemungkinan karena adanya rasa kurang percaya diri, khawatir, dan ragu-ragu dalam membawakan materi di fase awal mengajar (Sukaesih et al., 2017).

Pada kegiatan pendahuluan, mahasiswa memberikan pertanyaan apersepsi mengenai komponen Ekosistem kepada siswa, kemudian siswa menjawab dan mahasiswa menanggapinya. Pada kegiatan inti, mahasiswa menjelaskan tentang peranan komponen ekosistem, rantai makanan, dan jaring-jaring makanan. Kemudian, siswa duduk berkelompok untuk menjawab pertanyaan pada Lembar Kegiatan Siswa (LKS) dan menyusun beberapa gambar menjadi jaring-jaring makanan. Selanjutnya, perwakilan kelompok mempresentasikan hasil diskusinya diikuti dengan kegiatan menjawab pertanyaan dari kelompok lain. Setelah diskusi, mahasiswa membahas kembali pertanyaan-pertanyaan yang ada di LKS, tanpa menarik kesimpulan bersama siswa. Secara keseluruhan, dapat dikatakan bahwa mahasiswa hanya menggunakan metode ceramah selama kegiatan pembelajaran, meskipun beberapa kali terjadi kegiatan tanya jawab baik dari guru ke siswa, maupun sebaliknya. Pemilihan metode ini kurang tepat, karena metode ceramah untuk jumlah siswa yang relatif banyak dan pasif hanya akan memberikan sedikit pemahaman nyata kepada siswa (National Research Council, 1997). Materi seperti Ekosistem memerlukan keaktifan siswa untuk mengobservasi langsung lingkungan di sekitarnya (Sitanggang \& Yulistiana, 2015). Observasi akan mengasah kemampuan siswa untuk menggali pengetahuan dari setiap objek yang diamati (Rochintaniawati et al., 2009). Hal ini sejalan dengan buku pegangan guru (Widodo et al., 2017) yang menyarankan bahwa pada saat pembelajaran materi ekosistem ini sebaiknya menggunakan metode pengamatan langsung. Jika pun ada kendala untuk membawa siswa keluar kelas, akan lebih baik jika guru mengombinasikan metode ceramah dengan metode lain, misalnya role playing. Metode ini akan membuat siswa lebih memahami tentang peranan komponen ekosistem dan proses terjadinya jaringjaring makanan.

Mahasiswa PPL menggunakan metode ceramah untuk merangsang pengetahuan dasar siswa dengan memunculkan pertanyaan apersepsi berupa "apakah setelah berenang selama berjam-jam, kita akan berkeringat?" pada kegiatan pendahuluan. Pertanyaan yang merangsang pengetahuan dasar siswa seperti ini merupakan awal yang baik dalam memulai diskusi (Wierdsma et al., 2016). Setelah itu, pada bagian inti, mahasiswa PPL teramati menggunakan metode diskusi. Pemilihan metode diskusi pada pembelajaran pembentukan keringat sudah tepat. Siswa dilatih untuk berpikir kritis seiring jalannya diskusi (National Science Teachers Association, 2009), baik ketika mendengarkan pertanyaan guru, ataupun ketika mendengarkan pertanyaan dan sanggahan dari teman-temannya. Namun, mahasiswa PPL sebenarnya bisa mengemas kegiatan diskusi dengan melakukan rekontekstualisasi, yaitu dengan mengadaptasi konsep ekskresi di kulit ke dalam suatu konteks yang baru (Wierdsma et al., 2016). Selain itu, guru juga bisa menggunakan metode praktikum dengan meminta setiap kelompok melakukan beberapa aktivitas tertentu dan mengamati berbagai variabel yang mempengaruhi proses berkeringat setiap orang (misalnya apakah cepat lamanya seseorang dipengaruhi berat badan, suhu lingkungan, jenis aktivitas yang dilakukan, dsb). Hal ini sejalan dengan pernyataan Zubaidah et al. (2017) dalam buku pegangan guru yang menyarankan bahwa pada saat pembelajaran materi ekskresi ini sebaiknya menggunakan metode praktikum. Dengan demikian penggunaan metode yang dilakukan mahasiswa PPL kurang tepat.

Jika dibandingkan dengan mahasiswa dan mahasiswa PPL, guru berpengalaman menggunakan metode yang lebih variatif, yaitu metode ceramah, praktikum dan diskusi. Metode ceramah digunakan pada kegiatan awal pembelajaran, yaitu ketika guru mencoba menjelaskan mengenai konsep zat dan zat padat secara umum. Meskipun menggunakan metode ceramah, komunikasi yang terjadi tidak hanya satu arah dari guru saja. Awalnya, guru menayangkan beberapa gambar contoh-contoh zat padat, lalu menanyakannya kepada siswa. Siswa kemudian akan menjawab sesuai pengetahuan mereka, lalu selanjutnya 


\section{Jurnal Inovasi Pendidikan IPA, 7 (1), 2021 - 18}

Rusyda Mutanaffisah, Resmi Ningrum, Ari Widodo

guru akan memberikan jawaban dan penjelasan yang tepat. Kegiatan dilanjutkan dengan praktikum. Guru memberikan kesempatan kepada siswa untuk memahami LKS yang diberikan dan membiarkan siswa berdiskusi dan bekerja sama dalam kelompok untuk melakukan praktikum pengukuran massa jenis. Pemilihan metode praktikum ini sudah tepat (Bella \& Bachri, 2020). Hal ini sejalan dengan buku pegangan guru (Widodo et al., 2017) yang menyarankan bahwa pada saat pembelajaran materi massa jenis sebaiknya menggunakan metode praktikum. Siswa akan lebih mengingat konsep, terutama rumus dalam pelajaran fisika, dengan melakukannya sendiri. Selain itu, kegiatan praktikum adalah kegiatan yang dianggap menyenangkan oleh siswa dalam pelajaran sains (Maison et al., 2020). Pemilihan metode diskusi dalam materi ini juga tepat. Metode diskusi menjadi pilihan banyak guru IPA karena akan mengurangi intensitas penjelasan guru di depan kelas dan membuat siswa menjadi aktif dalam kegiatan pembelajaran (Insani, 2016). Dengan demikian metode pembelajaran guru berpengalaman sudah sesuai dengan yang disarankan dalam buku pegangan guru bahkan lebih variatif lagi. Hal ini sesuai dengan (Anwar et al., 2014) yang menyatakan bahwa hal yang membedakan antara guru berpengalaman dan tidak berpengalaman yaitu guru berpengalaman dalam memilih metode tidak hanya terkait dengan karakteristik materi tetapi juga terkait pada latar belakang dan karakteristik siswa. Selain itu guru berpengalaman lebih kepada penggunaan multi metode sedangkan guru tidak berpengalaman lebih cenderung kepada model-model pembelajaran.

\section{Pemilihan Media}

Dalam pemilihan media, dapat dilihat bahwa guru berpengalaman juga menggunakan media yang lebih variatif dibandingkan mahasiswa dan mahasiswa PPL. Di antara ketiganya, hanya guru berpengalaman pula yang sudah memilih media pembelajaran dengan tepat. Mahasiswa dan mahasiswa PPL hanya menggunakan media berupa gambar dua dimensi dan teks, bahkan belum secara optimal. Padahal jenis materi yang dibahas menuntut mereka untuk menggunakan media yang lebih tepat. Kurangnya variasi penggunaan media oleh mahasiswa calon guru menunjukkan mereka belum menerapkan pemahaman terhadap kurikulum, hakikat belajar, dan prinsip belajar aktif secara maksimal (Sukaesih et al., 2017).

Mahasiswa menggunakan media berupa teks yang ditampilkan pada slide power point. Media lainnya adalah gambar-gambar dua dimensi yang harus disusun oleh siswa secara berkelompok untuk membentuk jaring-jaring makanan. Padahal, media terbaik yang seharusnya dipilih mahasiswa dalam membahas materi "Ekosistem" adalah media asli yang dapat ditemui siswa lingkungan di sekitar siswa. Dengan melakukan observasi lingkungan, siswa akan mendapatkan pengalaman belajar yang tidak akan pernah dilupakannya. Pembelajaran juga akan berlangsung secara kontekstual karena siswa dapat melihat langsung teori yang dipelajari di buku dengan keadaan langsung di lapangan. Selain itu, penggunaan media laboratorium alam atau lingkungan terbukti dapat meningkatkan hasil belajar biologi siswa (Sitanggang \& Yulistiana, 2015). Hal ini sejalan dengan Widodo et al. (2017) dalam buku pegangan guru yang menyarankan bahwa pada saat pembelajaran materi ekosistem ini sebaiknya menggunakan media asli yang diperoleh dari lingkungan sekitar. Dengan demikian penggunaan media yang dilakukan mahasiswa kurang tepat.

Mahasiswa PPL menggunakan media gambar dua dimensi dalam membahas konsep mengenai aktivitas tubuh. Gambar yang digunakan berjumlah dua, yaitu berupa seseorang yang sedang berlari di bawah sinar matahari dan seseorang yang sedang berenang. Media gambar tersebut pada awalnya bisa menarik perhatian siswa, namun kemudian media tersebut menjadi kurang berguna. Media yang tepat untuk menjelaskan proses yang berlangsung dalam tubuh seperti proses pembentukan keringat adalah video dan model organ. Mahasiswa PPL seharusnya bisa memaksimalkan perkembangan media dan teknologi untuk menciptakan pengalaman belajar yang lebih menarik bagi siswa (Sack, 2019). Penggunaan video dan model organ akan membantu siswa mendapatkan visualisasi dari proses yang tidak dapat dilihatnya secara langsung, sehingga materi akan lebih dipahami siswa (Ilhamsyah, 2017). Selain itu, sebenarnya guru bisa memaksimalkan media asli. Proses pembentukan keringat merupakan proses alami yang bisa terjadi, dapat dibuktikan, dan bisa diamati oleh siswa. Guru bisa meminta siswa melakukan beberapa olahraga ringan yang bisa dilakukan di dalam kelas dan melihat reaksi tubuh yang terjadi setelahnya, dan membahasnya bersama. Hal ini sejalan dengan (Zubaidah et al., 2017) dalam buku pegangan guru yang menyarankan bahwa pada saat pembelajaran materi ekskresi (kulit) ini sebaiknya menggunakan media asli yaitu kulit. Media lain yang pernah digunakan dalam pembelajaran sistem ekskresi manusia adalah media permainan truth or dare (Rahayu \& Martini, 2019). Media ini 


\section{Jurnal Inovasi Pendidikan IPA, 7 (1), 2021 - 19}

Rusyda Mutanaffisah, Resmi Ningrum, Ari Widodo

terbukti dapat meningkatkan hasil belajar siswa. Dengan demikian, penggunaan media oleh guru PPL kurang tepat.

Selain menggunakan media teks dan gambar dua dimensi, guru berpengalaman menggunakan media berupa video tentang sejarah penemuan massa jenis dan berbagai benda padat yang akan digunakan selama praktikum. Hal ini sejalan dengan saran yang diberikan dalam buku pegangan guru (Widodo et al., 2017) bahwa pada saat pembelajaran materi massa jenis sebaiknya menggunakan media asli yang digunakan pada saat praktikum. Guru berpengalaman menggunakan berbagai media tersebut secara tepat. Materi pelajaran fisika seperti massa jenis memerlukan pengalaman belajar berupa eksplorasi besaran-besaran yang saling berkaitan dalam suatu formula. Siswa akan memahami hubungan antar besaran dengan pengukuran dan pembuktian langsung.

\section{SIMPULAN}

Hasil analisis video menunjukkan bahwa guru berpengalaman menggunakan strategi pembelajaran berupa pemilihan pendekatan, metode, dan media yang lebih variatif dibandingkan mahasiswa dan mahasiswa PPL. Selain itu, pemilihan tersebut juga sudah tepat digunakan selama kegiatan pembelajaran. Hasil analisis lebih lanjut menunjukkan bahwa hanya guru berpengalaman yang memaksimalkan kegiatan penutup untuk membahas konsep, baik yang telah dipelajari pada pertemuan hari itu ataupun mengaitkannya dengan pertemuan berikutnya. Namun, ada satu pola yang sama diantara ketiganya yaitu menggunakan kegiatan inti yang lebih dominan dibandingkan kegiatan pendahuluan dan kegiatan penutup.

\section{DAFTAR PUSTAKA}

Adi, Y. K., \& Widodo, A. (2018). Pemahaman hakikat sains pada guru dan siswa Sekolah Dasar. Edukasi Journal, 10(1), 55-72. https://doi.org/10.31603/edukasi.v10i1.1831

Ali, L. U., Suastra, I. W., \& Sudiatmika, A. (2013). Pengelolaan pembelajaran IPA ditinjau dari hakikat sains pada SMP di Kabupaten Lombok Timur. Jurnal Pendidikan Dan Pembelajaran IPA Indonesia, 3(1). http://119.252.161.254/e-journal/index.php/jurnal_ipa/article/view/750

Anwar, Y., Rustaman, N. Y., Widodo, A., \& Redjeki, S. (2014). Kemampuan pedagogical content knowledge guru biologi yang berpengalaman dan yang belum berpengalaman. Jurnal Pengajaran MIPA, 19(1), 69-73. https://doi.org/10.1017/CBO9781107415324.004

Anwar, Y., Rustaman, N. Y., Widodo, A., \& Redjeki, S. (2016). Perkembangan kemampuan pedagogical content knowledge (PCK) calon guru biologi pada pendekatan konkuren. Jurnal Cakrawala Pendidikan, 35(3), 349-356. https://doi.org/10.21831/cp.v35i3.8251

Bella, O. K., \& Bachri, B. S. (2020). Pengaruh model problem based learning terhadap hasil belajar pada materi massa jenis mata pelajaran ilmu pengetahuan alam kelas vii di sekolah menengah pertama Surabaya. Jurnal Mahasiswa Teknologi Pendidikan, 10(10).

Cakir, M. (2008). Constructivist approaches to learning in science and their implication for science pedagogy: A literature review. International Journal of Environmental and Science Education, 3(4), 193-206.

Chotimah, K., \& Hariyatmi. (2017). Gambaran kemampuan pedagogicalcontent knowledge guru IPA kelas VII SMP Negeri se-Kabupaten Sukoharjo. Seminar Nasional Pendidikan Biologi Dan Saintek II, 16, 671-678.

Darling-Hammond, L., Flook, L., Cook-Harvey, C., Barron, B., \& Osher, D. (2020). Implications for educational practice of the science of learning and development. Applied Developmental Science, 24(2), 97-140. https://doi.org/10.1080/10888691.2018.1537791

Großschedl, J., Harms, U., Kleickmann, T., \& Glowinski, I. (2015). Preservice biology teachers' professional knowledge: structure and learning ppportunities. Journal of Science Teacher Education, 26(3), 291-318. https://doi.org/10.1007/s10972-015-9423-6

Ilhamsyah, E. (2017). Pemanfaatan model ginjal dan LKS berjenjang dalam pembelajaran sistem ekskresi manusia untuk meningkatkan motivasi dan hasil belajar siswa kelas IX SMP Negeri 1 Wawo. Jurnal Ilmiah Mandala Education, 3(2), 232-242. https://doi.org/10.1017/CBO9781107415324.004 
Insani, M. D. (2016). Studi pendahuluan identifikasi kesulitan dalam pembelajaran pada guru IPA SMP se-Kota Malang. Jurnal Pendidikan Biologi, 7(2), 81-93.

Jumanto, \& Widodo, A. (2018). Pemahaman hakikat sains oleh siswa dan guru SD di Kota Surakarta. Jurnal Komunikasi Pendidikan, 2(1), 20-31. https://doi.org/10.32585/jkp.v2i1.61

Kastutik, A. W., \& Hariyatmi. (2017). Profil kemampuan Pedagogical Content Knowledge (PCK) guru IPA kelas VIII SMP Negeri di Kabupaten Sukoharjo. Seminar Nasional Pendidikan Biologi Dan Saintek II, 643-648.

Loughran, J., Berry, A., \& Mulhall, P. (2012). Understanding and developing science teachers' pedagogical content knowledge (2nd ed.). Sense Publisher.

Maison, M., Kurniawan, D. A., \& Pratiwi, N. I. S. (2020). Pendidikan sains di sekolah menengah pertama perkotaan: Bagaimana sikap dan keaktifan belajar siswa terhadap sains? Jurnal Inovasi Pendidikan IPA, 6(2), 135-145. https://doi.org/10.21831/jipi.v6i2.32425

Majid, A. (2008). Perencanaan pembelajaran mengembangkan standar kompetensi guru. PT Remaja Rosdakarya.

Mamlok-Naaman, R., Ben-Zvi, R., Hofstein, A., Menis, J., \& Erduran, S. (2005). Learning science through a historical approach: Does it affect the attitudes of non-science-oriented students towards science? International Journal of Science and Mathematics Education, 3(3), 485-507. https://doi.org/10.1007/s10763-005-0696-7

Mariana, I. M. A., \& Praginda, W. (2009). Hakikat IPA dan pendidikan IPA. Pusat Pengembangan dan Pemberdayaan Pendidik dan Tenaga Kependidikan Ilmu Pengetahuan Alam.

Maryanto, J., \& Hariyatmi. (2017). Profil pedagogical knowledge guru IPA kelas VIII SMP Muhammadiyah se-Kota Surakarta. Seminar Nasional Pendidikan Biologi Dan Saintek II, 666670.

McComas, W. F., Clough, M. P., \& Almazroa, H. (2002). The nature of science in science education: Rationales and strategies (W. F. McComas (ed.)). Kluwer Academic Publishers.

Mullis, I. V. S., Martin, M. O., Foy, P., \& Hooper, M. (2016). TIMSS 2015 international results in science. TIMSS \& PIRLS International Study Center, Boston College,.

National Research Council. (1997). Science teaching reconsidered: A handbook. The National Academies Press. https://doi.org/10.17226/5287

National Science Teachers Association. (2009). The biology teacher's handbook (4th ed.). BSCS NSTA Press.

Padila, T. M., Anwar, Y., \& Madang, K. (2017). Analisis kemampuan Pedagogical Content Knowledge (PCK) mahasiswa calon guru biologi FKIP Unsri sebelum dan setelah praktik mengajar. Prosiding Seminar Nasional Pendidikan IPA 2017, 571-581.

Putra, M. J. A., Widodo, A., \& Sopandi, W. (2017). Science teachers' pedagogical content knowledge and integrated approach. Journal of Physics: Conference Series, 895(1), 012144. https://doi.org/10.1088/1742-6596/895/1/012144

Rahayu, W., \& Martini. (2019). Penggunaan media permainan truth or dare pada materi ekskresi manusia untuk meningkatkan hasil belajar peserta didik di SMP Negeri 3 Sidoarjo. Jurnal Pendidikan Sains (JPS), 7(2), 279-283.

Rochintaniawati, D., Wulan, A. R., \& Sriyati, S. (2009). Kebutuhan guru sekolah dasar di Cimahi dan Kabupaten Bandung dalam melangsungkan pembelajaran IPA. Jurnal Penelitian, 10(2), 1-11.

Sack, J. D. (2019). Classroom materials and media reviews. The American Biology Teacher, 81(6), 459. https://doi.org/https://doi.org/10.1525/abt.2019.81.6.459. THE

Schleicher, A. (2019). PISA 2018: Insights and interpretations. OECD Publishing. https://www.oecd.org/pisa/PISA 2018 Insights and Interpretations FINAL PDF.pdf

Sitanggang, N. D. H., \& Yulistiana, Y. (2015). Peningkatan hasil belajar ekosistem melalui penggunaan laboratorium alam. Formatif: Jurnal Ilmiah Pendidikan MIPA, 5(2), 156-167. https://doi.org/10.30998/formatif.v5i2.335

Stigler, J. W., Gonzales, P., Kawanaka, T., Knoll, S., \& Serrano, A. (1999). The TIMSS videotape 


\section{Jurnal Inovasi Pendidikan IPA, 7 (1), 2021 - 21}

Rusyda Mutanaffisah, Resmi Ningrum, Ari Widodo

classroom study: Methods and findings from an exploratory research project on eighth-grade ,athematics instruction in Germany, Japan, and the United States (Issue February). U.S. Government Printing Office.

Sukaesih, S, Ridlo, S., \& Saptono, S. (2019). Development of biology teaching management textbooks based on competency and conservation to maximize Pedagogical and Content Knowledge (PCK) the prospective teachers. Journal of Physics: Conference Series, 1321(3), 1-6.

https://doi.org/10.1088/1742-6596/1321/3/032114

Sukaesih, Sri, Ridlo, S., \& Saptono, S. (2017). Profil kemampuan Pedagogical Content Knowledge (PCK) calon guru biologi. Lembaran Ilmu Kependidikan, 46(1), 68-74. https://doi.org/10.15294/lik.v46i2.11026

Widodo, A. (2017a). Teacher Pedagogical Content Knowledge (PCK) and students' reasoning and wellbeing. Journal of Physics: Conference Series, 812.

Widodo, A. (2017b). Experienced biology teachers' pedagogical content knowledge (PCK) on photosynthesis. AIP Conference Proceedings, 1848(May). https://doi.org/10.1063/1.4983985

Widodo, A. (2006). The feature of biology lessons: Results of a video study. Second UPI-UPSI Joint International Conference, 1-17.

Widodo, W., Rachmadiarti, F., \& Hidayati, S. N. (2017). Buku guru ilmu pengetahuan alam SMP/MTs kelas VII (Edisi Revi). Kementerian Pendidikan dan Kebudayaan.

Wierdsma, M., Knippels, M. C., van Oers, B., \& Boersma, K. (2016). Recontextualising cellular respiration in upper secondary biology education. Characteristics and practicability of a learning and teaching strategy. Journal of Biological Education, 50(3), 239-250. https://doi.org/10.1080/00219266.2015.1058842

Zubaidah, S., Mahanal, S., Yuliati, L., Dasna, I. W., Pangestuti, A. A., Puspitasari, D. R., Mahfudhillah, H. T., Robitah, A., Kurniawati, Z. L., Rosyida, F., \& Sholihah, M. (2017). Buku guru ilmu pengetahuan alam kelas VIII SMP/MTs. Kementerian Pendidikan dan Kebudayaan Republik Indonesia. 